\title{
American Adult T Cell Leukemia/Lymphoma: A Flow Cytometric and Morphological Study
}

\author{
BERTRAM SCHNITZER, LARRY E. KAHN, \\ EDMUND J. LOVETT, III, AND JERRY L. HUDSON \\ Flow Cytometry Laboratory \\ Department of Pathology \\ University of Michigan \\ Ann Arbor, Michigan 48109
}

\section{INTRODUCTION}

T-cell lymphomas and leukemias with a mature or post-thymic immunophenotype are uncommon in the United States and Europe, in contrast to Japan where they are frequent and where a distinctive type of adult T-cell leukemia/lymphoma (ATLL) is endemic in the southwestern part of the country. ${ }^{1}$ Occasional sporadic cases of ATLL have been reported in non-endemic areas of Japan, in the United States, and in several other countries. ${ }^{2-9}$ Within a two-year period, we have seen four patients from Michigan with ATLL at the University of Michigan. The neoplastic cells of three of these patients were immunophenotyped by flow cytometry (FCM) and FCM DNA analysis was carried out. Although the neoplastic cells of these patients had a helper cell (T4+) phenotype, phenotypic heterogeneity was detected within this population by FCM. A fourth patient, residing in Michigan but originating from an endemic area in Georgia, was extensively studied and previously reported as part of a larger series of cases. ${ }^{8.10,11}$ With the exception of the latter patient, all patients were leukemic and two of the four had hypercalcemia and antibodies to the C-type retrovirus, the human $\mathrm{T}$-cell leukemia virus (HTLV).

\section{MATERIALS AND METHODS}

\section{Light Microscopic Studies}

Blood and bone marrow smears were prepared and stained with Wright's stain, acid phosphatase, periodic acid-Schiff (PAS), and non-specific esterase (alpha-naphthol butyrate) using standard techniques. Tissue was fixed in B5 or neutral buffered formalin and sections stained with hematoxylin and eosin (H\&E).

\section{Electron Microscopic Studies}

Buffy coat preparations and tissue sections were fixed in a cacodylate-buffered solution containing $3 \%$ glutaraldehyde and $3 \%$ formaldehyde, processed accord- 
ing to previously reported techniques, ${ }^{12}$ and examined and photographed in a Zeiss 9S electron microscope.

\section{Immunologic Studies}

Cell surface antigen phenotyping of Ficoll-Hypaque-separated peripheral blood cells or minced tissue (skin and lymph nodes) was carried out with a battery of monoclonal antibodies. These included: T11, T10, T9, T6, T8, T4, I2 (HLA/DR), J5 (CALLA), B1, B2, Mo1, Mo2, IgG, IgM, IgA, IgD, kappa, lambda (Coulter Immunology), Tac (kindly provided by Dr. T.A Waldmann), Leu 7 (Becton-Dickinson), and TdT (immunofluorescence) (Bethesda Research Laboratories). Staining was performed by an indirect immunofluorescent procedure. Double staining in case 3 was carried out using a single fluorochrome (FITC) and a cocktail of primary antibodies. To determine whether the Tac antigen was present exclusively on T4+ or T8+ lymphocytes, the Ficoll-Hypaque-separated cells were stained with the following monoclonal antibodies: T4, T8, Tac, T4 and Tac, T8, and Tac (TABle 1). Sorting of T4+, T8+, T4+ Tact, and T8+ Tac negative populations was carried out and the sorted populations were examined morphologically. DNA staining was carried out on Ficoll-Hypaque-separated cells using a propidium iodide (PI) solution according to Vindelov. ${ }^{13}$ Chicken erythrocytes were used as an internal DNA standard. An aliquot of the chicken erythrocytes was added to the suspension of leukocytes and stained with PI. DNA histograms were collected as a linear signal and the peak position of the chick cells was translocated to the same channel number. The number of cycling cells was calculated by integration of the $S$ and $G_{2} M$ regions of the histogram and expressed as percent of total nuclei counted. Assays for serum antibodies against disrupted HTLV were performed by previously published techniques. ${ }^{14}$

\section{Case 1}

A previously healthy 44-year-old white male from Michigan initially complained of constipation, abdominal discomfort, and distention. He had lost 8-10 pounds in the preceding three weeks. He noted generalized lymphadenopathy and a white blood cell count of over $100 \times 10^{9} / 1$ was found. Pertinent physical findings included enlarged lymph nodes in the cervical and clavicular areas, a 2

TABLE 1. Relationship of $\mathrm{T} 4+, \mathrm{T} 8+$, and Tac+ Cells (Case 3)

\begin{tabular}{lc}
\hline Marker & \% Positive \\
\hline Control & 0 \\
T4 & 75 \\
T8 & 17 \\
Tac & 40 \\
T4 + Tac (cocktail) & 75 \\
SUM (T4, Tac) & 115 \\
T8 + Tac (cocktail) & 56 \\
SUM (T8, Tac) & 57 \\
\hline
\end{tabular}


$\mathrm{cm}$ right axillary lymph node and bilateral inguinal nodes $1-2 \mathrm{~cm}$ in diameter. Liver and spleen were enlarged. Laboratory values were: hemoglobin $14.0 \mathrm{~g}$, hematocrit 43 , white blood count $95 \times 10^{9} / 1$ with $98 \%$ abnormal lymphocytes with hyperlobulated nuclei (FIgURE 1A), and a platelet count of $50 \times 10^{9} / 1$. Serum calcium was $9.1 \mathrm{mg} / \mathrm{dl}$. Serum antibodies to disrupted HTLV viral particles were not detected. A bone marrow biopsy revealed foci of normal hematopoiesis, but large areas of the marrow were overrun by hyperlobulated lymphocytes. The patient was treated with vincristine, prednisone, and intrathecal methotrexate. The white blood cell count initially fell to $50 \times 10^{9} / 1$ but subsequently rose to $140 \times 10^{9} / 1$. More aggressive therapy with vincristine, doxorubicin, and prednisone resulted in a transient disease in the $\mathrm{WBC}$, but the patient's condition worsened, and he died 22 days after the diagnosis of his illness. At necropsy, widespread leukemic infiltrates were found.

\section{Case 2}

A 78-year-old white female was diagnosed as having chronic lymphocytic leukemia (CLL) at another hospital. Her white blood cell count was $98.9 \times 10^{9} / 1$ with $91 \%$ lymphocytes. The patient refused therapy. No skin lesions were detected. The spleen was palpated $10 \mathrm{~cm}$ below the left costal margin, and the liver was enlarged below the right costal margin. Two months later she was admitted to the University of Michigan Hospital in a cachectic state. Bilateral pulmonary effusions were present. Sputum grew out acid-fast bacilli, and she was treated with INH, Rifampin, and pyridoxine. The white blood cell count was $174 \times 10^{9} / 1$ with $91 \%$ lymphocytes. The hemoglobin was $12.7 \mathrm{mg} / \mathrm{dl}$, hematocrit $34.5 \%$, platelet count $124 \times 10^{9} / 1$. The lymphocytes were small to medium-sized with multilobulated nuclei (FIGuRE 1B). A bone marrow biopsy showed diffuse infiltration by lymphocytes with irregular nuclear contours. A morbiliform skin rash was biopsied and abnormal lymphoid cells were seen in the dermis as well as exocytosis of cells into the epidermis. The patient was treated with cytoxan, vincristine, and prednisone. As this therapy was not effective, she was given Deoxycoformycin, which was effective in reducing her white blood cell count but did not control her systemic disease. She continued to have pleural effusions containing neoplastic lymphocytes with the same phenotype as the cells in the peripheral blood. The patient died eight months after diagnosis. An autopsy was not performed.

\section{Case 3}

A 76-year-old male was admitted to the University of Michigan Hospital for "hepatitis" and "confusion." A serum calcium was found to be $17.1 \mathrm{mg} / \mathrm{dl}$. Positive findings on physical examination included several $2 \times 2 \mathrm{~cm}$ lymph nodes in the right axilla, shotty left axillary lymph nodes, and bilateral inguinal lymph nodes about $2 \times 2 \mathrm{~cm}$ in size. The spleen was not palpable, and the liver was $3 \mathrm{~cm}$ below the costal margin with a $10 \mathrm{~cm}$ span. The hemoglobin at admission was $18.4 \mathrm{mg} /$ dl, hematocrit $56.7 \%$, white blood count $20.4 \times 10^{9} / 1$, and the platelet count was $156 \times 10^{9} / 1$. The differential white blood cell count contained $44 \%$ lymphocytes, most of which were hyperlobulated (FIGURE 1C). The patient was treated with saline, Lasix, a single dose (350 units) of calcitonin, and $100 \mathrm{mg}$ Solu-medrol. 


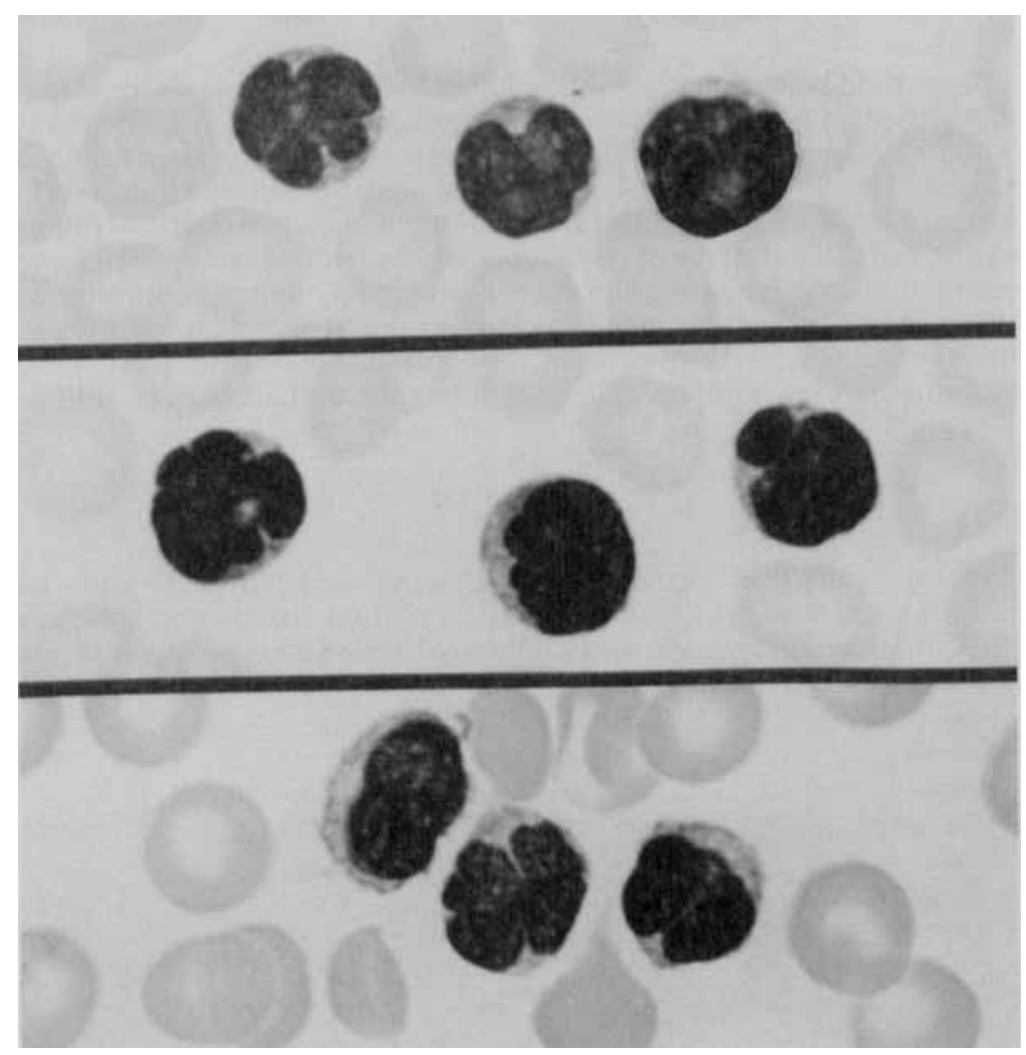

FIGURE 1. Multilobulated neoplastic lymphocytes from the peripheral blood of the three leukemic cases. (A) Case 1, (B) Case 2, (C) Case 3. Wright's stain $\times 1300$.

During the next four days, the serum calcium dropped to $10.2 \mathrm{mg} / \mathrm{dl}$. Over the next week, the white blood count rose to $32.8 \times 10^{9} / 1$ with $68 \%$ lymphocytes and then fell to $20 \times 10^{9} / 1$ with $80 \%$ lymphocytes. Examination of spinal fluid showed no abnormal lymphocytes. A bone marrow aspirate and biopsy contained less than $10 \%$ abnormal lymphocytes. During the course of illness, the patient developed pleural effusions and ascites. On numerous occasions, abnormal lobulated lymphocytes with the same phenotype as the blood lymphocytes were present in fluids from both cavities. Over the next four weeks, the enlarged lymph nodes became smaller, and the number of abnormal lymphocytes in the blood decreased progressively until several days before the patient died, when abnormal cells were no longer detected in the blood. Occasional hyperlobulated lymphocytes were still noted in the ascitic fluid several days before death. The patient died six weeks after onset of his illness. No evidence of lymphoma or leukemia was detected in autopsy tissue. Severe cytomegalovirus infection was detected in lungs, larynx, pancreas, adrenal glands, urethra, and kidneys. 
Case 4

A 30-year-old black female, who resided in Michigan but was born in Georgia, initially presented with skin rash and hypercalcemia of $18 \mathrm{mg} / \mathrm{dl}$. She refused an operation for parathyroidectomy and reappeared one month later with a serum calcium of $23 \mathrm{mg} / \mathrm{dl}$. Lytic bone lesions were noted. Several skin biopsies (FIGURE 2) revealed a large cell lymphoma (T-cell immunoblastic sarcoma). A lymph node biopsy showed the same type of lymphoma. The patient was treated with a variety of chemotherapeutic regimens with short-lived remissions and with reappearance of skin lesions. Further treatment was carried out at the National Institutes of Health. She was never leukemic during the course of her disease. The patient died two and one-half years after a diagnosis of lymphoma had been established.

\section{RESULTS}

The leukemic cells from cases 1,2, and 3 were similar by light and electron microscopy as well as cytochemically. Both in blood smears and bone marrow aspirates, the lymphocytes were medium sized with varying degrees of nuclear lobulations ranging from slight to pronounced, some having a mulberry

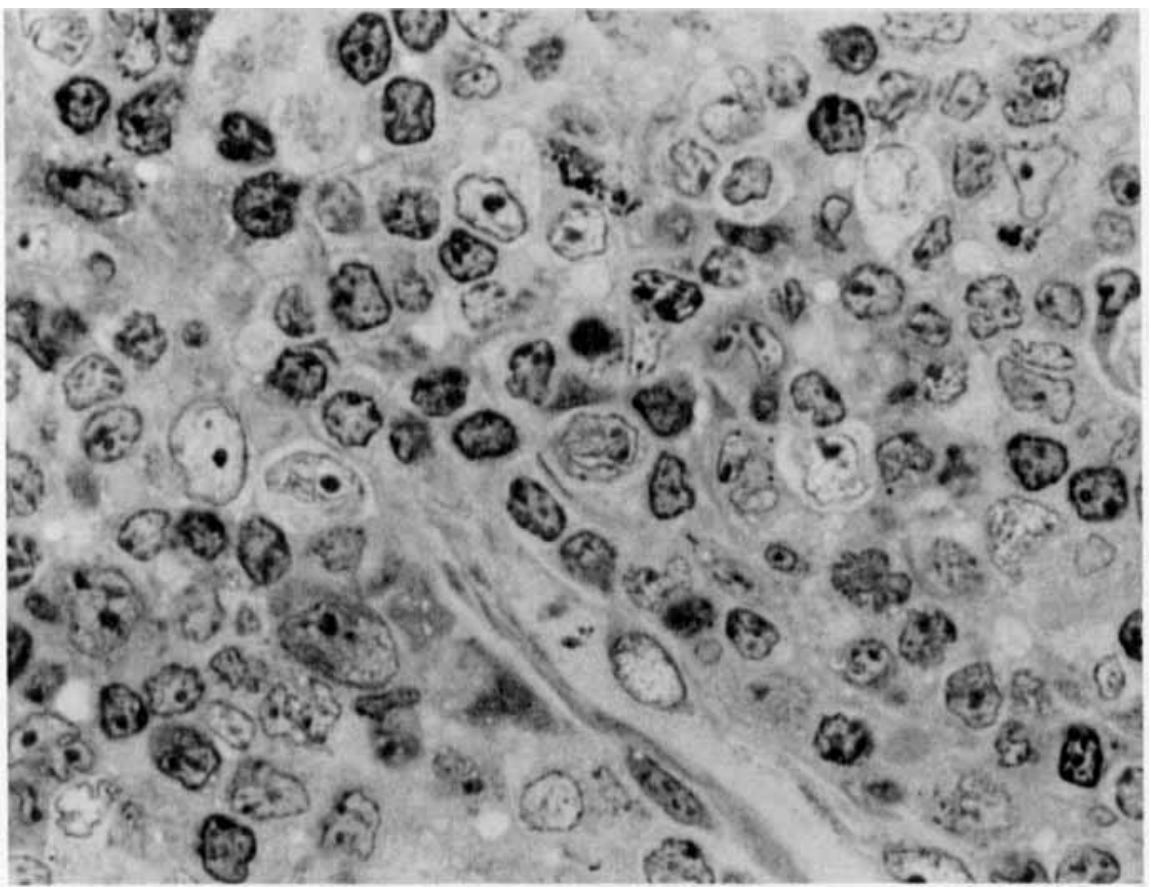

FIGURE 2. Lymph node biopsy from Case 4 showing a predominance of large neoplastic cells, some of which have markedly irregular nuclear contours. H\&E $\times 500$. 
appearance (FIGURE 1). In most cells, in both peripheral blood as well as in smears of bone marrow aspirates, the nuclear chromatin was aggregated and nucleoli were not evident, while in somewhat larger cells, nuclear chromatin was less aggregated and a single nucleolus was noted (FIGURE 1). In all cases, the cytoplasm of the cells was diffusely punctate acid phosphatase positive, while NSE and PAS stains were negative. Ultrastructurally, the neoplastic cells showed varying degrees of nuclear lobulation and nucleoli were inconspicuous in most cells but prominent in a few cells (FIGUREs 3-5). The neoplastic cells in the skin and lymph node biopsies of case 4 consisted predominantly of large cells, some of which had irregular nuclear contours, while others had round to oval nuclei with single nucleoli (FIGURE 2). Most of the cells had ample cytoplasm. Scattered smaller lymphoid cells with irregular nuclei and prominent nucleoli. The lymphocytes in case 3 had greater nuclear irregularity than in the other three cases and nuclear blebs and pocket formation were more often observed (FIGURE 5 ). In cases 2 and 4 small dense granules were noted in the cytoplasm of some cells. In all cases, the cytoplasm of the neoplastic cells contained moderate numbers of ribosomes, scattered mitochrondria, and rare segments of rough endoplasmic reticulum with collapsed cisternae. Serum antibodies to disrupted HTLV viral particles were detected in cases 3 and 4. Elevated levels of serum calcium were also noted in cases 3 and 4 (TABLE 2).

Cell surface antigen phenotyping by FCM varied slightly from patient to patient (TABLE 2 ). In case 1 , over $90 \%$ of neoplastic cells were $\mathrm{T} 11+, \mathrm{T} 3+, \mathrm{T} 4+$,

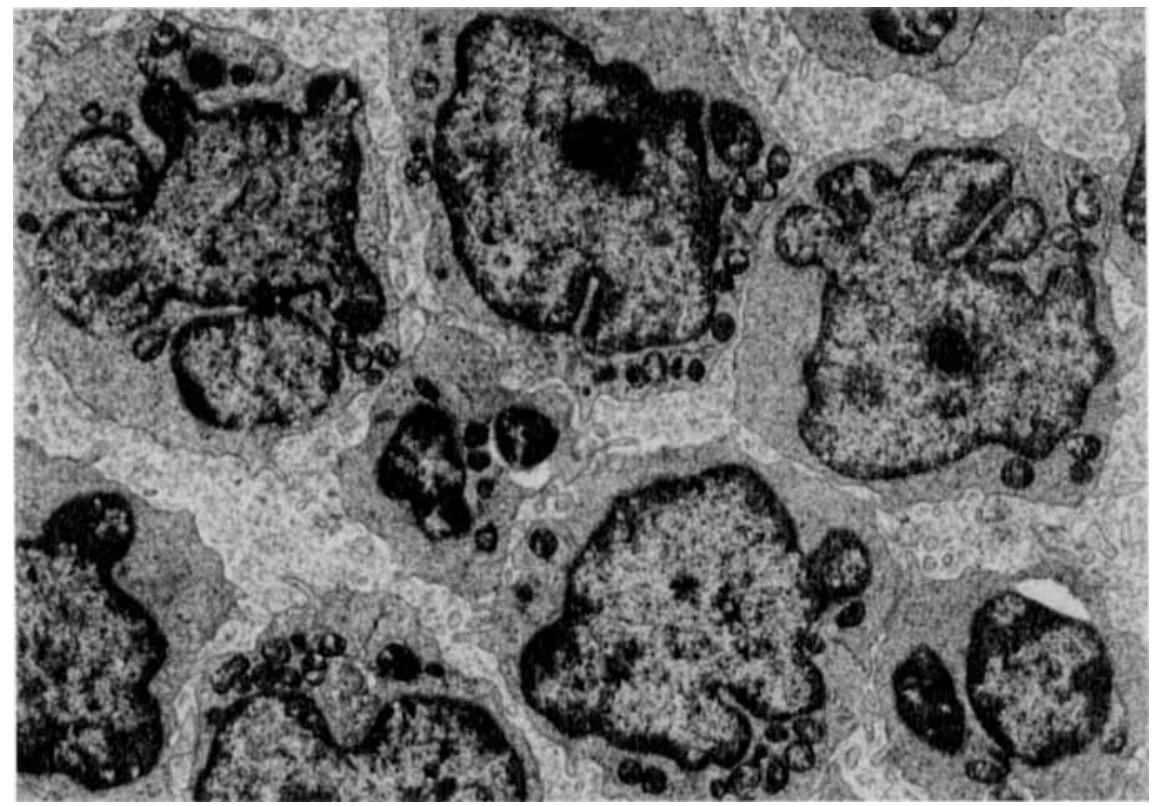

FIGURE 3. Electron micrograph of leukemic cells from the peripheral blood of Case 1. Multilobulated nuclei are evident. $\times 8,300$. Figure reduction $70 \%$. 


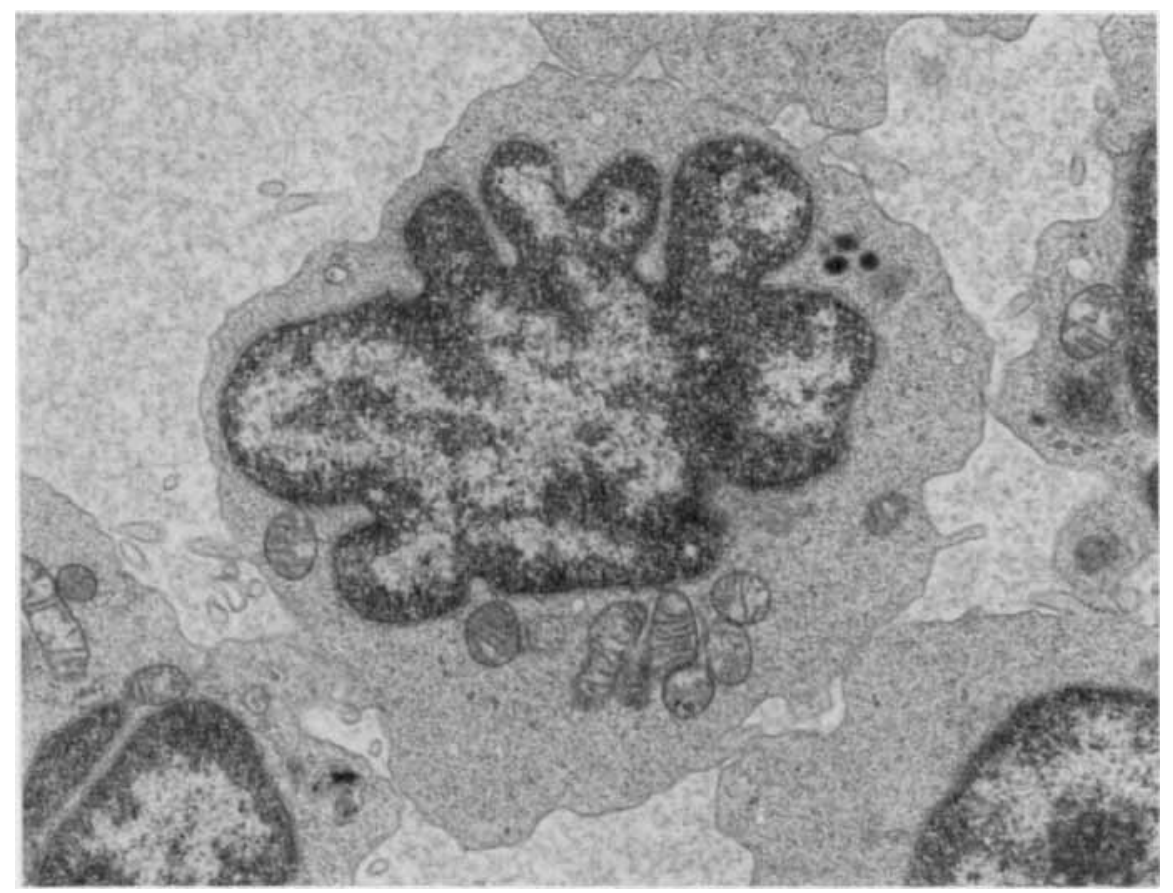

FIGURE 4. Electron micrograph of a leukemic lymphocyte of Case 2. The nucleus is multilobulated and the cytoplasm contains three dense granules and a number of mitochondria. $\times 10,000$.

T8 + . They did not express antigens detected by monoclonal antibodies T10, T9, T6, Ia, J5 (CALLA), Leu 7, B1, B2, and surface immunoglobulin (SIg) light and heavy chains were not detected. In case 2 , the neoplastic cells had the following phenotype: T11+, T3+, T4+, T8-, T10-, T9-, Ia-, J5(CALLA)-, Leu 7-, B1-, B2-, and SIg light and heavy chain negative (TABLE 2), whereas the cells in case 3 had the phenotype: $\mathrm{T} 11+, \mathrm{T} 10+, \mathrm{T} 3+, \mathrm{T} 4+$, and Tac $+\left(\mathrm{T}_{\mathrm{ABLE}} 2\right)$. Forty percent of the neoplastic lymphocytes were $\mathrm{Tac}+$, and all of these bore the T4 antigen, while none of $\mathrm{T} 8+$ cells were Tact (TABLE 1). The neoplastic cells did not express antigens detected by monoclonal antibodies T9, T8, T6, Ia, J5 (CALLA), Leu 7, B1, B2; and SIg light and heavy chains were absent. In case 4 , the phenotype of the malignant cells in skin and lymph node was $\mathrm{T} 11+, \mathrm{T} 3+, \mathrm{T} 4+$, and $\mathrm{T} 8-$. In all cases, the neoplastic cells lacked TdT. DNA analysis failed to detect aneuploidy. In all of the cases, the number of cells in the $S$ and $G_{2} M$ phase of the cell cycle was not increased over those of normal peripheral blood lymphocytes.

\section{DISCUSSION}

It is important to differentiate T-cell from B-cell lymphoproliferative disorders, because the former often have a more fulminant clinical course and require more 


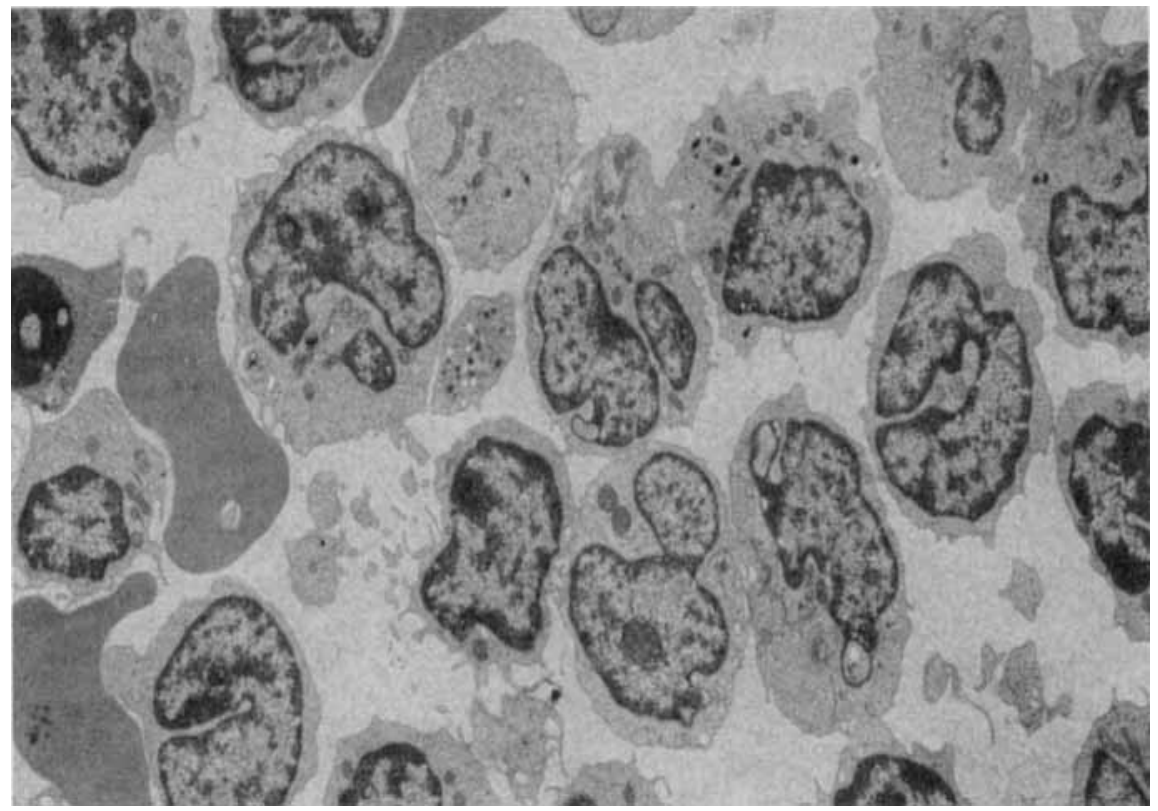

FIGURE 5. Electron micrograph of leukemic cells of Case 3 . The nuclei are irregular and nuclear bleb formation is evident. $\times 4,300$. Figure reduction $70 \%$.

aggressive therapy. This is especially true of cases of ATLL, which in most instances are associated with a median survival of less than one year. ${ }^{6-11}$

In endemic as well as non-endemic regions, the most characteristic feature of ATLL is the presence of pleomorphic multilobulated lymphocytes in the peripheral blood. ${ }^{6-11}$ Infiltrates of these abnormal lymphoid cells are the cause of lymphadenopathy, hepatosplenomegaly, skin lesions, and, less frequently, pulmonary lesions. ${ }^{9-11}$ More common in endemic areas are hypercalcemia at the time of diagnosis or during the course of the disease, and antibodies to HTLV, which are present in 90 to $100 \%$ of cases from Japan and from the Caribbean. ${ }^{7.9-11.15-19}$ The mediastinum, which is frequently involved in T-cell lymphoblastic lymphoma, is spared in ATLL. One of three of our non-endemic patients had serum antibodies to HTLV, and all patients were leukemic, while the patient born in the endemic region was not leukemic but presented with hypercalcemia and skin lesions and subsequent involvement of lymph nodes. As in almost all reported patients with ATLL, the lymphocytes of three of four of our patients had a helper cell phenotype. ${ }^{7-11.20}$ The other patient had an anomalous phenotype, hitherto unreported in ATLL. The neoplastic cells had both a helper and suppressor cell phenotype $(\mathrm{T} 11+, \mathrm{T} 3+, \mathrm{T} 4+, \mathrm{T} 8+, \mathrm{T} 6 \mathrm{i}, \mathrm{T} 10-),{ }^{6}$ which does not conform to the scheme of allegedly normal intrathymic $T$-cell differentiation. ${ }^{21}$ In the three leukemic cases phenotyped by FCM, the neoplastic cells of case 3 did express the non-lineage specific T10 antigen. Thus, despite identical cytologic features of these $\mathrm{T} 4+$ leukemic cells, phenotypic heterogeneity was detected by FCM (TABLE 2). 


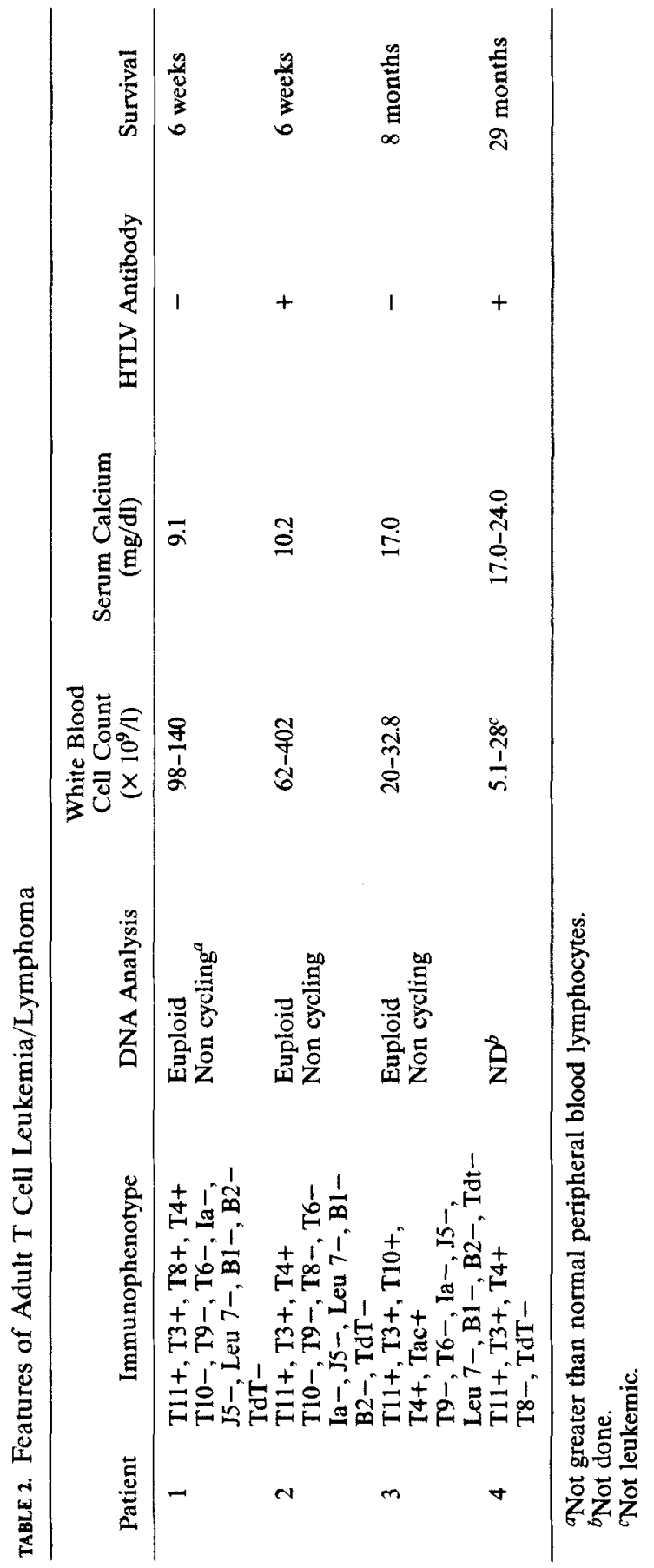


Relatively little has been reported about HTLV seronegative cases of ATLL. $5,7,8$ The two cases in this series in which no HTLV antibodies were demonstrated were, except for the absence of hypercalcemia, clinically and morphologically identical to our seropositive cases as well as to seropositive cases reported previously. In all three cases, the leukemic cells were multilobulated both by light and electron microscopy and had diffuse punctate acid phosphatase positivity. The HTLV's positive case is highly unusual in that the patient had a spontaneous remission of his disease prior to death, but died with a severe CMV infection similar to endemic cases of ATLL, in which patients not infrequently contract infections by opportunistic agents. ${ }^{9}$ Another case of ATLL with spontaneous remission has been reported in Japan. ${ }^{22}$

The neoplastic cells of case 3 were analyzed with the anti-Tac monoclonal antibody. This antibody, which detects the receptor for the human T-cell growth factor or interleukin 2 (IL2) does not bind to normal resting T lymphocytes, B lymphocytes, or monocytes. ${ }^{23-25}$ Tac monoclonal antibody does, however, identify HTLV-positive ATLL cells. ${ }^{23,24}$ It is therefore useful not only in confirming a diagnosis of ATLL but also in differentiating other T-cell lymphoproliferative disorders, such as Sezary syndrome, in which the neoplastic T-helper cells may cytologically mimic those seen in ATLL. ${ }^{26}$ Since it has been established that HTLV is T-cell tropic infecting primarily cells with a helper phenotype, ${ }^{26,27}$ the Tac antigen should bind only to neoplastic T4+ cells and not to T8+ cells. In the HTLV+ case 3, in which the neoplastic cells were tested and found to react with anti-Tac antibody, multiparameter analysis was employed, revealing that the $\mathrm{T} 4+$, but not the T8+, cells were Tact. We reached this conclusion on the basis of staining the cells with one fluorochrome and a cocktail of primary antibodies. It was assumed that if the Tac antigen is present on either the T4+ or T8+ lymphocytes, the sum of cells positive for the individual markers would be greater than that of their respective cocktails (T4 or T8+Tac). If the Tac antigen is not present on either T4+ or T8+ cells, then the sum of the percent of cells positive for the individual markers should be approximately equal to their respective cocktails. TABLE 1 summarizes the results of this double-staining procedure. Additional evidence that Tac was present only on T4+ was provided by sorting of $\mathrm{T} 4+$, Tact and $\mathrm{T} 8+$, Tac - populations. The sorted $\mathrm{T} 4+\mathrm{Tac}+$ cells were the neoplastic hyperlobulated acid phosphatase-positive lymphocytes, while the $\mathrm{T} 8+$, Tac- population were cytologically small, normal-appearing lymphocytes (FIGURE 6). The hypercalcemia in this patient may be explained by the presence of

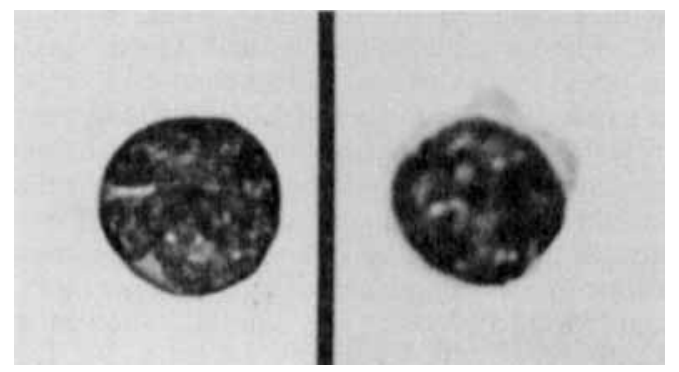

FIGURE 6. (Left) Sorted T4+ Tac+ leukemic cell with hyperlobulated nucleus. (Right) Sorted T8+ Tac - small lymphocyte. Wright's stain $\times 1,300$. 


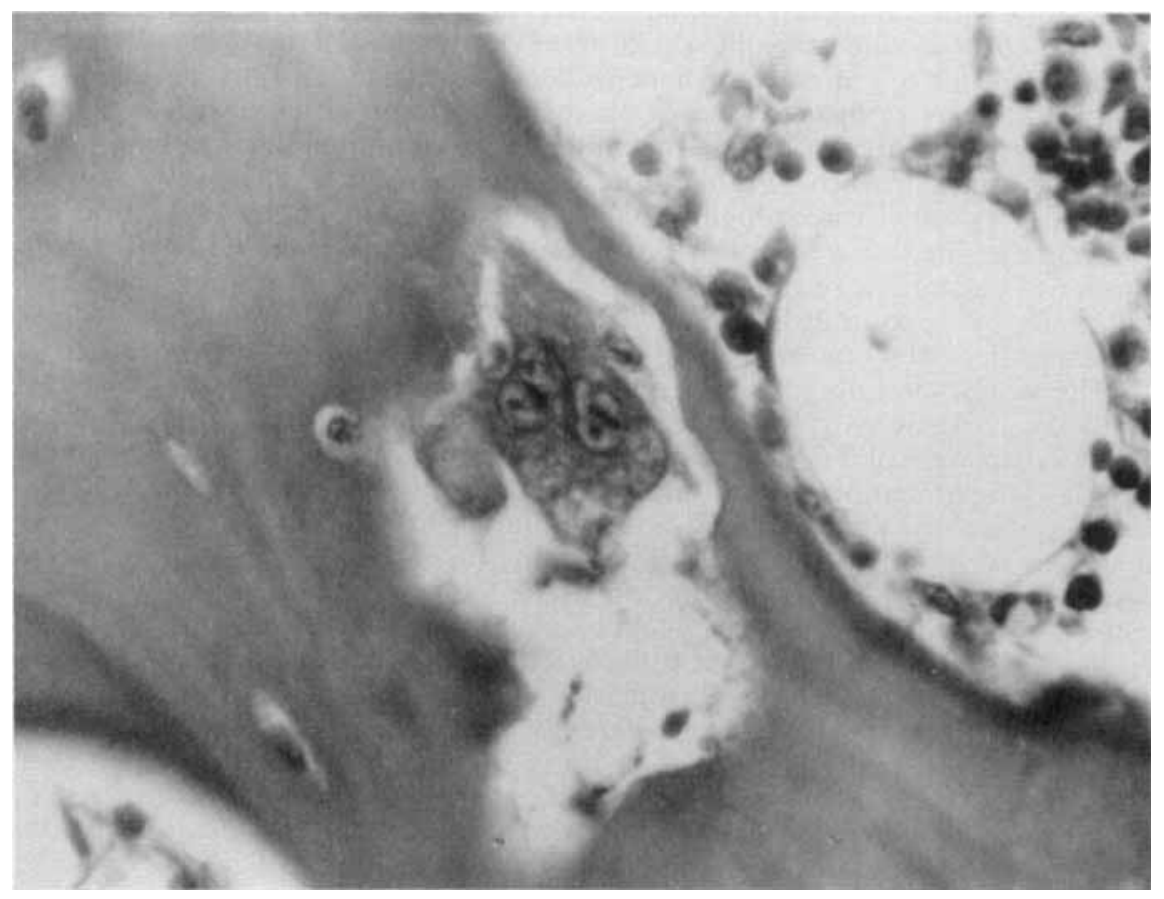

FIGURE 7. Bone and marrow from Case 3 showing scalloping of trabecular bone and an osteoclast. $\mathrm{H} \& \mathrm{E} \times 200$.

increased osteoclastic activity with scalloping of trabecular bone, which was evident in the bone of this patient despite the absence of associated leukemic marrow infiltrates (FIGURE 7). This feature has been reported in endemic cases from the United States and is thought to be due to a lymphokine produced by the neoplastic cells. ${ }^{2}$

In summary, three cases of non-endemic ATLL were analyzed by FCM. Cytologically, the leukemic cells were identical. In two cases, the cells had a helper phenotype, while in a third case both helper and suppressor cell markers were found in the same cells. A fourth patient, originating from an endemic area in Georgia, but residing in Michigan, also had a helper cell phenotype. Phenotypic heterogeneity among the neoplastic helper cells was detected by FCM. Mutliparameter analysis and cell sorting by FCM is useful in detecting more than one surface marker on the same cell and was essential in identifying the IL2 receptor on neoplastic helper cells. DNA analysis by FCM failed to detect an aneuploid population, and cell cycle analysis showed a low proliferative activity of ATLL cells. 


\section{REFERENCES}

1. Uchiyama, T., J. Yodoi, K. Sagawa, L. TaKatsuki \& H. Uchino. 1977. Blood 50(3):481491.

2. Grossman, B., G. P. Schechter, J. E. Horton, L. Pierce, E. S. Jaffe \& L. Wahl. 1981. Am. J. Clin. Pathol. 75(2):149-155.

3. KADIN, M. E. \& M. KAMOUN. 1982. Lancet I(8279):1016-1017.

4. Kadin, M. E. \& M. Kamoun. 1982. Human Pathol. 13(8):691-693.

5. Takenaka, T., H. Nakamine, I. Oshiro, J. Maeda, M. Kobori, T. Hayashi, H. Komoda, Y. Hinuma \& M. Hanaoka. 1983. Jpn. J. Clin. Oncol. 13(Suppl. 2):257268.

6. Schnitzer, B., E. J. Lovett, III, J. L. Hudson, K D. McClatchey, D. F. Keren, L. DABICH \& B. F. MITCHELL. 1982. Lancet II(8310):1273-1274.

7. SChNitzer, B., E. J. Lovett, III \& L. E. KaHN. 1983. Lancet II(8357):1030.

8. KADIN, M. E., C. W. BERARD, K. NANBA \& H. WAKASA. 1983. Human Pathol. 14(9):745772.

9. BunN, P. A., G. P. Schechter, E. S. Jaffe, D. W. Blayney, R. C. Young, M. J. Mathews, W. A. Blattner, S. Broder, M. Robert-Guroff \& R. C. Gallo. 1983 N. Engl. J. Med. 309(5):257-264.

10. Jaffe, E. S., W. A. Blattiner, D. W. Blayney, P. A. Bunn, JR., J. Cossman, M. RobertGuRofF \& R. C. Gallo. 1984. Am. J. Surg. Pathol. 8(4):263-275.

11. Blayney, D. W., E. S. JafFe, W. A. Blattner, J. Cossman, M. Robert-Guroff, D. L. Longo, P. A BUNN, JR. \& R. C. Gallo. 1983. Blood 62(2):401-405.

12. SChNitzer, B. \& L. Kass. 1974. Am. J. Clin. Pathol. 61(2):176-187.

13. Vindelov, L. L. 1977. Virchows Arch. (Cell Pathol.) 24(3):227-242.

14. Robert-Guroff, M., V. S. Kalyanaraman, W. A. Blattner, M. Popovic, M. G. Sarngadharan, M. Maeda, D. Blayney, D. Catovsky, P. A Bunn, JR., A. Shibata, Y. NAKAO, Y. ITO, T. AOKI \& R. C. Gallo. 1983. J. Exp. Med. 157(1):248-258.

15. Blattner, W. A., V. S. Kalyanaraman, M. Robert-Guroff, T. A. lister, D. A. G. Calton, P. Serin, M. H. Crawford, D. Catovsky, M. F. Greaves \& R. C. Gallo. 1982. Int. J. Cancer 30(3):257-264.

16. Robert-Guroff, M., Y. NAKao, K. Notake, A. Sliski \& R. C. Gallo. 1982. Science 215(4535):975-978.

17. Catovsky, D., M. Rose, A. W. G. Goolden, J. M. White, G. Bourikas, A. I. Brownell, W. A Blattiner, D. A. G. Galton, D. R. McCluskey, I. A. Lampert, R. Ireland, J. M. Bridges \& R. C. Gallo. 1982. Lancet I(8273):639-643.

18. Blayney, D. W., E. S. Jaffe, W. A. Blattner, J. Cossman, M. Robert-Guroff, D. L. Longo, P. A. BunN \& R. C. Gallo. 1983. Blood 62(2):401-405.

19. Blattiner, W. A., W. N. Gibbs, C. Saxinger, M. Robert-Guroff, J. Clark, W. Lofters, B. Hanchard, M. Campbell \& R. C. Gallo. 1983. Lancet II(8341):6164.

20. Hatford, T., T. Uchiyama, T. Tolbana, K. Takatsuki \& H. Uchino. 1981. Blood 58(3): 546-547.

21. Reinherz, E. L., P. C. Kung, G. Goldstein, R. H. Levey \& S. F. Schlossman. 1980. Proc. Natl. Acad. Sci. USA 77(3):1588-1592.

22. Kimura, I., T. Tsubota, K. Hayashi \& T. Ohnoshi. 1983. Jpn. J. Clin. Oncol. 13(Suppl. 2): $231-236$.

23. UChiyama, T., S. Broder \& T. A. WaldManN. 1981. J. Immunol. 126(4):1393-1397.

24. Uchiyama, T., D. L. Nelson, T. Fleisher \& T. A. Waldmann. 1981. J. Immunol. 126(4):1398-1403.

25. Leonard, W. J., J. M. Deeper, T. Uchiyama, K. A. Smith, T. A. Waldmann \& W. C. GREENE. 1982. Nature 300(5889):267-269.

26. Broder, S., P. A. Bunn, E. S. Jaffe, W. Blattner, R. C. Gallo, F. Wong-Staal, T. A. Waldmann \& V. T. Devita. 1984. Ann. Int. Med. 100(4):543-557.

27. Robert-GurofF, M. \& R. C. Gallo. 1983. Blut 47(1):1-12. 